\title{
Pharmacognostic Studies and In Vitro Antioxidant Potential of Traditional Polyherbal Formulation of West Sikkim with Asparagus Spp
}

\author{
Arunika Subba and Palash Mandal ${ }^{*}$ \\ Department of Botany, Plant Physiology and Pharmacognosy Research Laboratory, University of North Bengal, Siliguri, West Bengal, India.
}

\begin{abstract}
Introduction: The powder mixture of the two species of Asparagaceae (Asparagus filicinus and Asparagus officinalis) was found to be used traditionally for the treatment of heart palpitation in west Sikkim. Objective: Pharmacognostic characterisation was carried out for the authentication of the powder drug which included powder microscopy, fluorescence analysis and physicochemical characterisation. The presence of any therapeutic potential in HP was also determined by qualitative and quantitative estimation of phytochemicals along with free radical scavenging activity of various successive solvent extracts (based on their polarity). Thin layer chromatography (TLC) of the powdered HP was also done. The standard software SPSS (ver. 15.0) and XLSTAT 2009 (Addinsoft) and Smith's Statistical Package were used for different statistical analysis. Results: Powder microscopy of HP revealed the presence of calcium oxalate crystal, tracheids, stone cells etc. Various fluorescence colours were exhibited by HP on UV after reacting with different chemical reagents. The analysis values were also obtained in a satisfactory way. TLC and qualitative phytochemical analysis revealed the presence of some active phytoconstituents. Among all the solvent extracts, acetone, heptane, ethyl acetate and benzene extracts showed higher antioxidant potential. Conclusion: The results support the use of HP as a traditional medicine and further purification should be done for the identification of bioactive phytoconstituents responsible for its antioxidant activity.
\end{abstract}

Key words: Antioxidant, Pharmacognostic evaluation, Phytoconstituents, Successive solvent extraction, Thin layer Chromatography.

\section{SUMMARY}

- HP powder prepared from the roots of Asparagus officinalis and Asparagus filicinus is used to cure heart palpitation in the traditional system at a village in west Sikkim.

- Powder was subjected for some pharamacognostic characterisation methods and the result of which might be helpful in authentication of the traditional drug.

- Some phytoconstituents such as anthraglycosides, arbutin, cardiac glycosides, flavonoids, bitter principles and coumarins were revealed on the sample by separating through thin layer chromatography. Alkaloids and saponins were absent.

- Qualitative evaluation of phytochemicals revealed presence of cardiac glycosides and flavonoids in all solvent extracts while amino acid and triterpenoids in few extracts only and showed absence of tannin, resin and alkaloids.
- Antioxidants potential varied in different solvent extracts but overall acetone and heptane extracts were better than other extracts.

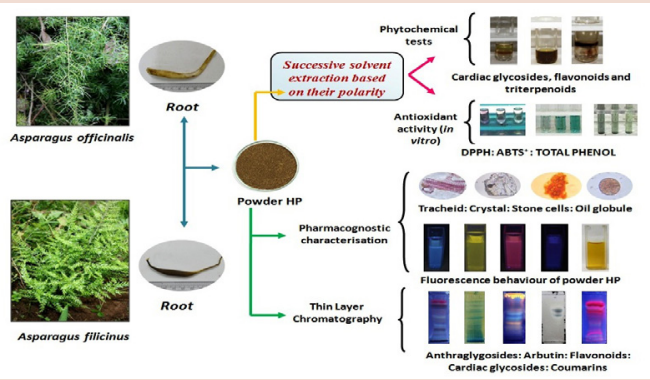

PICTORIAL ABSTRACT

Abbreviations used: HP: powder polyherb for heart palpitation, HPHx: Hexane extract, HPHp: Heptane extract, HPBz: Benzene extract, HPEa: Ethyl acetate extract, HPCl: Chloroform extract, HPAc: Acetone extract, HPBu: Butanol extract, HPEt: Ethanol extract, HPMt: Methanol extract, HPAq: Aqueous extract, TLC: Thin layer chromatography, DPPH: 1, 1-diphenyl-2-picrylhydrazyl scavenging activity, ABTS+: 2,2'-azinobis-3-ethylbenzothiozoline-6-sulphonic acid scavenging activity, SO: Superoxide scavenging activity, NO: Nitric oxide scavenging activity, MC: Metal chelating activity, FRAP: Ferric reducing antioxidant power, TPC: Total phenol content, TFC: Total flavonol content, TOPC: Total orthodihydric phenol content, GAE/mg EW: Gallic acid equivalent/mg extractive weight, $\mathrm{QE} / \mathrm{mg} \mathrm{EW}$ : quercetin equivalent/mg extractive weight, AAE/mg EW: Ascorbic acid equivalent/ mg extractive weight.

\section{Correspondence:}

Dr. Palash Mandal, Department of Botany, Plant Physiology and Pharmacognosy Research Laboratory, University of North Bengal, Siliguri, West Bengal, P.O. 734 013, India.

Phone no: +919434886123

Email: nbubotanypm@gmail.com

DOI : 10.5530/pj.2015.6.6

\section{INTRODUCTION}

Since ancient times, plants have been used as herbal medicines to heal various ailments. Recently, there is widespread interest growing on drugs derived from plants because they are reliable, safe and cost effective compared with expensive synthetic drugs causing adverse effects in human health. Most of the noble drugs used in modern medicines are produced indirectly from medicinal plants ${ }^{1}$ and about $90 \%$ of raw materials come from wild sources. But ethnomedicinal knowledge has still now confined to certain areas or group of people due to the lack of effective scientific communication. ${ }^{2}$ Hence it is quite essential to establish the potential of herbal medicine and encourage the study of folk knowledge about medicinal plants. ${ }^{3}$ In fact pharmaceutical and clinical investigations have raised the position of medicinal plants by identifying the active principle components present in them and elaborating their role in human and animal systems. ${ }^{4}$

Sikkim is a small Himalayan state $\left(7096 \mathrm{~km}^{2}\right.$ geographical area) in Northeast region of India harbouring an extremely rich diversity of medicinal plants. Over the ages, Sikkim has developed rich cultural practices of folk medicines. ${ }^{5}$ Asparagus officinalis Linn. and Asparagus filicinus Buchanon-Hamilton ex. D.Don., both belonging to family Asparagaceae are commonly used ethnomedicinal plants. Young stems of A. officinalis are used for the treatment of constipation and intestinal disorders. ${ }^{6}$ Tubers of A. filicinus is traditionally used for the treatment of diarrhoea, dysentery, 
diabetes $^{7}$ and it was also found to have antiviral activity against Influenza virus $\mathrm{A} .{ }^{8}$ Our survey revealed that the polyherbal formulation (HP) is made by mixing the roots of both the plants by an herbal practitioner for the treatment of heart palpitation. However the medicine prepared by traditional methods may not have the desired quality and batch to batch consistency. Hence this formulation required standardization with scientific parameters including organoleptic characters, physicochemical analysis and microscopy.

Recently the role of medicinal plants in disease control or prevention has been credited to antioxidant properties of their constituents usually polyphenolic compounds. ${ }^{9}$ The intake of natural antioxidants are related to minimizing the risks of common but hazardous diseases like cancer, diabetes, cardiovascular problems, and many other diseases related with ageing. ${ }^{10,11}$ Natural antioxidants have been observed in various unexplored plant resources like wild fruits, ${ }^{12}$ leafy vegetables ${ }^{13}$ and even bryophytes. ${ }^{14}$ Extraction of antioxidants from a plant material can be done by using different techniques and different solvents as these compounds have diverse chemical nature and often unique distribution in the plant matrix. ${ }^{15,16}$ Solvent extraction is the most commonly used method for recovery of the plant antioxidants; however, the yields and antioxidant value of the plant extracts are strongly dependent on the polarity of the solvent plus the chemical nature of the isolated compounds. ${ }^{17}$

Literature survey did not yield any information about pharmacognostic studies of the above polyherb. There were no records provided on the antioxidant activity also. Therefore this study was focused on the standardization of HP, which was made from the roots of $A$. officinalis and A. filicinus, by measuring various attributes such as powder microscopy, fluorescence analysis and physicochemical studies. To explore the presence of active phytoconstituents, qualitative and quantitative phytochemicals content were also done along with free radicals scavenging activities of HP extracted in different solvents.

\section{MATERIALS AND METHODS}

\section{Collection and authentication of plant material}

A polyherbal powder sample prepared from the roots of $A$. officinalis and $A$. filicinus in equal ratio was collected from an herbal practitioner from Uttarey, West Sikkim in April, 2014. The herbarium specimen was identified and authenticated by Dr. A.P. Das, Professor, Taxonomy and Environmental Biology Laboratory, Department of Botany, University of North Bengal. The voucher specimens were deposited at laboratory herbarium, Taxonomy and Environmental Biology Laboratory, University of North Bengal against accession no. 09724/Tag no. E.S. 05 and 09723/ Tag no. E.S. 04 for Asparagus filicinus Buchanon-Hamilton ex. D.Don., and Asparagus officinalis Linn. respectively.

\section{Sample preparation}

The powder sample was extracted through soxhlet apparatus in 10 different solvents based on their polarity. The solvent extracts were hexane (HPHx), heptane (HPHp), benzene (HPBz), ethyl acetate (HPEa), chloroform ( $\mathrm{HPCl}$ ), acetone (HPAc), butanol (HPBu), ethanol (HPEt), methanol (HPMt) and water (HPAq). The samples were then evaporated and reconstituted in methanol. These extracted samples were used for qualitative and quantitative estimation of phytochemicals and determination of free radical scavenging activities. For TLC and pharmacognostic studies, the sample was used in its powder form.

\section{Pharmacognostic characterization}

\section{Organoleptic evaluation and Powder microscopy}

The colour, odour, taste and texture of the powder of HP were observed and recorded. ${ }^{18}$ Microscopic examination was carried out in a standard method. ${ }^{19} \mathrm{~A}$ small amount of powder of HP was taken on glass slide and mounted on glycerine and observed under microscope. For the observation of lignified tissues, powder was stained with alcoholic solution of phloroglucinol followed by concentrated $\mathrm{HCl}$. Similarly the powder was also stained with N/10 iodine solution to observe the starch granules and for the identification of fixed oil and fats, Sudan III were used.

\section{Fluorescence behaviour}

The powder sample as such and after treatment with various chemical reagents was subjected to fluorescence analysis. Observations were made under visible light and under UV light of short $(254 \mathrm{~nm})$ and long wave length $(365 \mathrm{~nm})$ separately. ${ }^{20}$

\section{Physico-chemical parameters}

Coarse powder of the plant root was used to perform quality control parameters such as total ash, acid insoluble and water soluble ash, water and alcohol soluble extractive values and loss on drying. ${ }^{21}$ Three determinations were carried out for each parameter.

\section{Preliminary photochemical studies}

The HP powder extracted in various solvents were subjected for preliminary phytochemical screening to observe the presence or absence of phytoconstituents like tannin, triterpeniods, amino acid, resin, cardiac glycosides and flavonoids by the standard methods. ${ }^{22-25}$

\section{Thin layer chromatography}

TLC was performed to analyse the variation in bioactive chemical constituents. ${ }^{26}$ Readymade TLC plates (coated with silica gel $60 \mathrm{~F}_{254}$ on aluminium sheets) purchased from Merck Germany were used. The powdered sample was extracted with different procedures for the identification of each of the active constituents i.e. anthraglycosides, arbutin, cardiac glycosides, flavonoids, bitter principles, saponins, coumarins and alkaloids. The mobile phase solvent systems used were ethyl acetate: methanol: water (100:13.5:10) for the detection of anthraglycosides, arbutin, cardiac glycosides, bitter principles and alkaloids. The mobile phase ethyl acetate : formic acid : glacial acetic acid : water (100:11:11:26) was used for flavonoids identification and for the identification of saponin, the solvent system of chloroform: glacial acetic acid : methanol: water $(64: 32: 12: 8)$ was used while for the identification of coumarins, toluene : ethyl acetate (93:7) was used. The developed chromatograms were analyzed for presence of drug constituents by spraying with an appropriate group reagent/s. The chromatograms were then observed under UV-254 nm and UV-365 nm light. Photos were taken with DSLR Nikon camera (D-3200) and the $R_{f}$ values were calculated with the following formula.

$$
R_{f}=\frac{\text { Distance travelled by solute }}{\text { Distance travelled by solvent }}
$$

\section{Quantitative evaluation of phytochemicals}

\section{Total phenol content (TPC)}

Folin-Ciocalteu reagent was used to determine the TPC of HP. ${ }^{27}$ The absorbance was measured at $725 \mathrm{~nm}$ in UV-visible spectrophotometer. Total phenol values were expressed in terms of Gallic acid equivalent (GAE)/mg Extractive weight (EW).

\section{Total flavonol content (TFC)}

TFC was measured with the mixture consisted of methanolic extract with Sodium nitrite $\left(\mathrm{NaNO}_{2}\right)$, Aluminium chloride $\left(\mathrm{AlCl}_{3}\right)$ and Sodium hydroxide $(\mathrm{NaOH}) .{ }^{17}$ The absorbance was measured at 510 $\mathrm{nm}$. TFC in different extracts was calculated as quercetin equivalent $(\mathrm{QE}) / \mathrm{mg}$ EW. 


\section{Total ortho-dihydric phenol content (TOPC)}

TOPC was estimated according to standard method by using Arnow's reagent. ${ }^{28}$ The OD values were taken at $515 \mathrm{~nm}$. TOPC was calculated from a catechol standard curve.

\section{Evaluation of antioxidants}

\section{DPPH radical scavenging activity}

The free radical scavenging activity of all the solvent fractions of HP was evaluated using DPPH. ${ }^{29}$ Discoloration of these extracts was measured at $517 \mathrm{~nm}$ after incubation for 10 minutes in dark at room temperature. Percentage of inhibition was calculated with the following formula:

$$
\frac{I=A_{0}-A_{1}}{A_{0}} \times 100 \quad \text { Equation (1) }
$$

where $\mathrm{A}_{0}=$ absorbance of the control, $A_{1}=$ absorbance of the sample (different fractions of HP), I=percent inhibition of DPPH by the sample.

\section{ABTS ${ }^{+}$scavenging activity}

The $\mathrm{ABTS}^{+}$free radical scavenging activity of all the solvent fractions of HP was done. ${ }^{30}$ The diluted ABTS ${ }^{+}$solution $(2 \mathrm{ml})$ was added to $1 \mathrm{ml}$ methanolic sample. The scavenging activity of sample was observed and absorbance was read at $734 \mathrm{~nm}$ after 10 minutes of incubation. The percentage inhibition was calculated by using Equation (1).

\section{Superoxide scavenging assay (SO)}

A standard method was used with some slight modifications to carry out SO scavenging activity. ${ }^{31}$ Superoxide anions are produced in the PMS/
NADH-NBT system. The decrease in absorbance shows the radical scavenging activity of the sample which was measured at $560 \mathrm{~nm}$. The inhibition percentage was calculated by Equation (1).

\section{Inhibition of nitric oxide production (NO)}

At a physiological $\mathrm{pH}$, aqueous sodium nitroprusside generates nitric oxide (NO) which produces nitrite after interacting with oxygen which can be estimated by Greiss reagent. ${ }^{32}$ The diazotization of nitrite with sulphanilamide following its coupling with naphthylethylenediamine forms chromophore, the absorbance of which was measured at $546 \mathrm{~nm}$. Equation (1) was used to calculate the percentage inhibition.

\section{Metal chelating assay (MC)}

The chelation of ferrous ions by HP extracts was estimated..$^{33}$ The colour complex formed by the chelation of $\mathrm{Fe}^{2+}$ by ferrozine was reduced by the chelating activity of sample competing with ferrozine was measured at $562 \mathrm{~nm}$. The inhibition percentage was calculated using Equation (1).

\section{Ferric reducing antioxidant power (FRAP)}

The FRAP of the HP extracts was determined on the ability of the sample to reduce ferric ions. ${ }^{34}$ Absorbance was measured in UV-VIS spectrophotometer at $700 \mathrm{~nm}$. Ascorbic acid was taken as standard.

\section{Statistical analysis}

The standard software SPSS (ver. 15.0) was used for different statistical analysis. One-way analysis of variance (ANOVA) was used to compare the differences and the means which were considered significant at $\mathrm{p} \leq 0.05$. Correlation and regression analysis were done by using XLSTAT 2009 (Addinsoft) and Smith's Statistical Package.

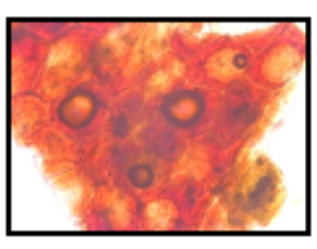

(a)

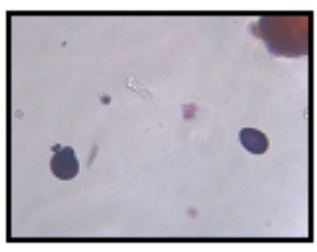

(d)

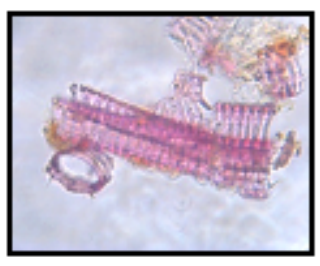

(g)

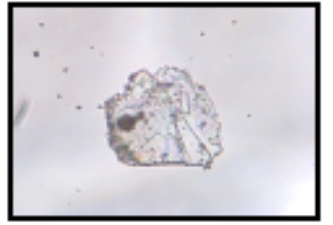

(b)

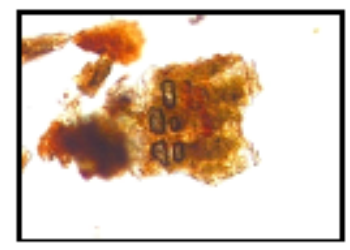

(e)

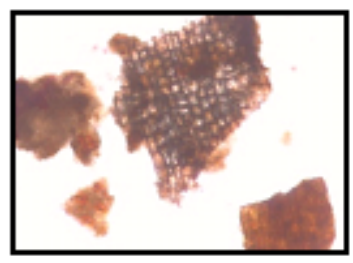

(h)

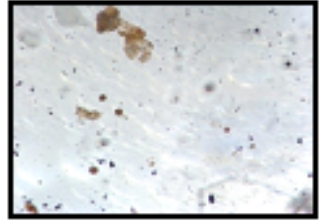

(c)

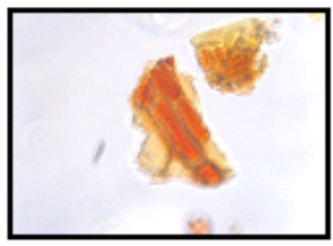

(f)

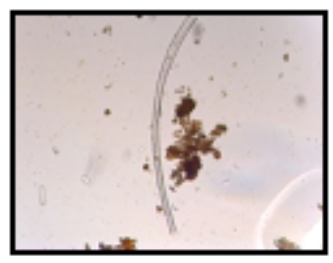

(i)

Figure 1: Powder microscopy of polyherb, HP

a) Collenchyma b) Prismatic calcium oxalate crystal c) Oil globules d) Starch e) Stone cells f) Parenchymatous cells g) Scalariform tracheid h) Cork cells i) Fiber 
Table 1: Fluorescence analysis of powder HP

\begin{tabular}{|c|c|c|c|}
\hline Reagents & Visible & UV-254 & UV-365 \\
\hline $\begin{array}{c}\text { Powder + distilled } \\
\text { water }\end{array}$ & Green beige & Azure blue & Brilliant blue \\
\hline Powder $+50 \% \mathrm{KOH}$ & Red orange & Colourless & Black green \\
\hline Powder + benzene & Sulphur yellow & Curry yellow & Broom yellow \\
\hline $\begin{array}{c}\text { Powder }+50 \% \\
\text { benzene }\end{array}$ & Fern green & Colourless & Raspberry red \\
\hline Powder + chloroform & Colourless & Colourless & Distant blue \\
\hline $\begin{array}{l}\text { Powder + } 50 \% \\
\text { chloroform }\end{array}$ & Fern green & $\begin{array}{c}\text { Pearl } \\
\text { blackberry }\end{array}$ & Rose \\
\hline $\begin{array}{l}\text { Powder + nitric acid } \\
\quad \text { (conc.) }\end{array}$ & Broom yellow & Colourless & Colourless \\
\hline $\begin{array}{c}\text { Powder }+\mathbf{5 0} \% \text { nitric } \\
\text { acid }\end{array}$ & Broom yellow & Colourless & Colourless \\
\hline $\begin{array}{c}\text { Powder }+10 \% \text { ferric } \\
\text { chloride }\end{array}$ & Broom yellow & Colourless & Colourless \\
\hline Powder + methanol & Colourless & Cobalt blue & Ultramine blue \\
\hline $\begin{array}{c}\text { Powder + 50\% } \\
\text { methanol }\end{array}$ & Khaki grey & Grey blue & Gentian blue \\
\hline Powder + ethanol & Colourless & Cobalt blue & Ultramine blue \\
\hline $\begin{array}{c}\text { Powder }+50 \% \\
\text { ethanol }\end{array}$ & Olive grey & Pearl night blue & Traffic blue \\
\hline $\begin{array}{l}\text { Powder }+ \text { glacial } \\
\text { acetic acid (conc.) }\end{array}$ & Reed green & Yellow olive & Brown beige \\
\hline $\begin{array}{l}\text { Powder }+50 \% \text { glacial } \\
\text { acetic acid }\end{array}$ & Green beige & No colour & Ultramine blue \\
\hline $\begin{array}{l}\text { Powder + sulphuric } \\
\text { acid (conc.) }\end{array}$ & Ochre brown & Colourless & Blue grey \\
\hline $\begin{array}{l}\text { Powder }+50 \% \\
\text { sulphuric acid }\end{array}$ & Ochre yellow & Colourless & Grey blue \\
\hline
\end{tabular}

\section{RESULTS}

\section{Organoleptic and powder microscopic evaluation}

The powder of HP was brown in colour, slightly rough in texture and slightly bitter in taste. It had a characteristic smell. Powder microscopy revealed calcium oxalate crystal, parenchymatous cells, fiber, collenchyma, stone cells, cork cells and scalariform tracheid (Figure 1).

\section{Fluorescence analysis}

The powder of HP exhibited different colours after treating with different chemical reagents. The colours were observed in daylight and under ultraviolet (UV) light at $254 \mathrm{~nm}$ and $365 \mathrm{~nm}$. The colours were identified and noted down in Table 1 using the standard colour chart of RAL.

\section{Physicochemical characteristics}

The results obtained from physicochemical studies were given in Table 2. The result of total ash (20.24\%) showed that the powder HP contains both organic and inorganic matter. Total ash is mainly essential to check the purity of drugs showing the presence or absence of metallic salts or silica ${ }^{35,36}$ which was found to be $20 \% \mathrm{w} / \mathrm{w}$. The percentage of ash was calculated with reference to the air-dried powder. The acid insoluble ash was noted as $16 \% \mathrm{w} / \mathrm{w}$ while the presence of material exhausted by water i.e. the water soluble ash was recorded to be $14 \% \mathrm{w} / \mathrm{w}$. Determination of extractive values is another way of checking the purity of the herbal formulation. The water soluble extractive value was found to be $3.21 \% \mathrm{w} / \mathrm{w}$ which signifies that more amount of constituents in HP was soluble in
Table 2: Physicochemical analysis of powder of HP

\begin{tabular}{cc}
\hline Parameter & Value \\
\hline Total Ash(\%) w/w & 20.243 \\
Acid insoluble ash(\%) w/w & 16.011 \\
Water soluble ash(\%) w/w & 14.01 \\
Alcohol soluble extractive value(\%) & 0.441 \\
w/w & \\
Water soluble extractive value(\%) & 3.211 \\
w/w & 10.52 \\
Loss on drying(\%) w/w & 6.79 \\
$\mathbf{p H}(\mathbf{1} \% \mathbf{w} / \mathbf{v})$ & 6.38 \\
$\mathbf{p H}(\mathbf{1 0} \% \mathbf{w} / \mathbf{v})$ &
\end{tabular}

water than in alcohol $(0.441 \% \mathrm{w} / \mathrm{w})$. The percentage of loss on drying i.e. the moisture content in the powder was found to be $10.52 \% \mathrm{w} / \mathrm{w}$.

\section{Thin layer chromatography}

Preliminary investigation of active constituents in plants was carried out by thin layer chromatography (TLC) technique. After applying specific spraying reagents for a particular active constituent, the results of TLC showed the presence of anthraglycosides, arbutin, flavonoids, cardiac glycosides and coumarins in HP. $\mathrm{R}_{\mathrm{f}}$ values were calculated for all the spots and the results of this analysis are described in Table 3.

\section{Qualitative phytochemical analysis}

The pharmacological activity of the crude drug mainly depends on the metabolites present in it. Thus preliminary screening of phytochemicals which was performed to establish a chemical profile of a crude drug was a part of chemical evaluation. ${ }^{37,38}$ These phytochemical tests (Table 4) revealed the presence of cardiac glycosides and flavonoids in different extracts of HP obtained by using different solvents. Tannins, alkaloids and resins were absent while amino acid was found to be present in aqueous extract only and triterpenoids were found to be present in few extracts (acetone, butanol, ethanol, methanol and water).

\section{Antioxidant activity}

In the present study, various methods such as $\mathrm{DPPH}, \mathrm{ABTS}^{+}, \mathrm{SO}, \mathrm{NO}$, MC, FRAP were used to evaluate the antioxidant potential of HP. The sample was prepared in a soxhlet apparatus successively in various solvents (non-polar to polar). TPC, TFC and TOPC were also estimated quantitatively for HP (Table 5). The highest TPC was exhibited by heptane extract (361.41 mg GAE/mg EW) followed by acetone (272.99 mg GAE/mg EW). The highest TFC content (15.45 mg GAE/mg EW) was shown by benzene extract. For the radical scavenging activity, it is very clear from Table 5 that the acetone extract of $\mathrm{HP}$ showed the lowest $\mathrm{IC}_{50}$ values for $\mathrm{DPPH}, \mathrm{ABTS}^{+}$and superoxide scavenging assays along with highest ferric reducing power indicating the highest antioxidant activity. The same extract showed excellent quantity of TPC and TFC also.

\section{DISCUSSION}

Traditional medicine has always played an important role in primary health care. But for the proper utilization of this medicine, each and every formulation mentioned in our indigenous knowledge of medicine should be scientifically evaluated. ${ }^{39}$ Therefore the powder of HP was subjected to certain standardization parameters. Despite of the availability of various modern tools for the evaluation of plant drugs, powder microscopy is still considered as the simplest and cheapest method for identification of the source materials. ${ }^{40}$ When powder of HP was subjected to microscopic analysis, starch granules were revealed after staining with iodine solution while Sudan III stain showed the presence of 
Table 3: Detection of active phytoconstituents in powder HP by TLC method

Ethyl acetate: methanol: water (100:13.5:10)

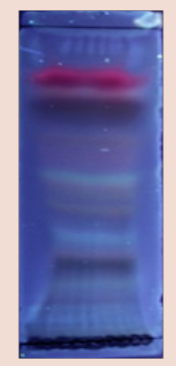

Red band=Anthraglycosides

Ethyl acetate: Formic acid:

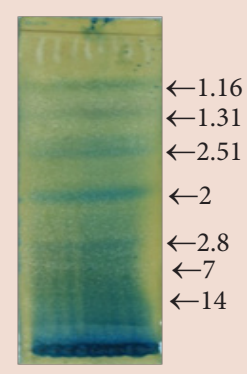

Blue band=Arbutin

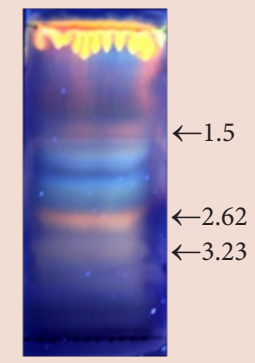

Yellow to orange bands=Flavonoids

Chloroform: Glacial acetic acid: Methanol: Water (64:32:12:8)

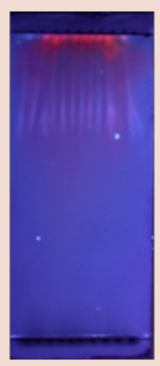

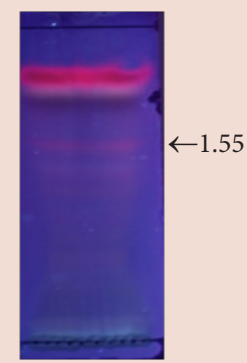

Red band=Bitter Principles

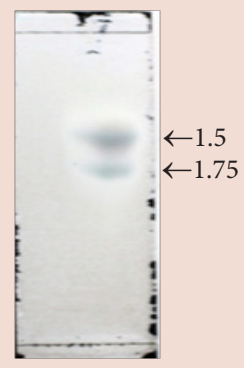

Blue band=Cardiac Glycosides

Toluene: Ethyl acetate (93:7)

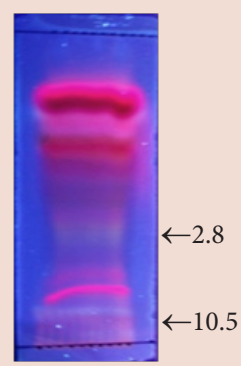

Blue band=Coumarin

Ethyl acetate: methanol: water (100:13.5:10)

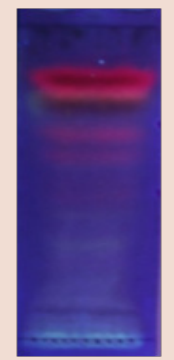

Brown band= alkaloids (Absent)

oil globules in the powder. Lignified tissues appeared pink in colour distributed abundantly after staining with phloroglucinol solution. Fluorescence study is also an important parameter for standardization of crude drug. Various chemical constituents present in plant materials exhibited fluorescence when suitably illuminated. Fluorescence colour of each compound is very specific. But if those chemicals itself are not fluorescent then they may be treated with different chemical reagents to attain fluorescence..$^{41}$ The quality and purity of crude drugs can also be checked by ash values. It indicates the presence of various impurities in crude drugs due to adulteration or incorrect processing during drying or storage or formulation. The water soluble ash shows the amount of acid, sugars and inorganic matter present in the powder while acid insoluble ash shows mainly silica thus indicating the contamination with earthy materials. ${ }^{42}$ The extractive values are useful to evaluate the chemical constituents present in crude drug and also help for estimation of specific constituents soluble in a particular solvent. For any drugs and herbal formulation, low moisture content is essential for higher stability of drugs. The general requirement for moisture in a crude drug should not be more than $14 \% \cdot{ }^{43}$ Excess moisture content may support the growth of fungi and may cause contamination by other microorganisms resulting into the degradation of drug. But HP powder showed $10 \%$ of moisture content i.e. loss on drying percentage (Table 2) which is not too high to encourage the growth of microorganisms. The pharmacological importance of a drug is attributed to the various secondary metabolites present in it and a particular compound might possess a clinical significance. Therefore it is essential to separate the compounds present in the plants with an appropriate chromatographic method. TLC technique has proved its worth as a simple, inexpensive and reproducible method for the chemical and biological screening of plant extracts. It provides a basic idea of polarity of a particular chemical constituent. ${ }^{44}$ Development of TLC plates with appropriate group reagents indicates the presence of anthraglycosides, arbutin, flavonoids, cardiac glycosides and coumarins in HP powder. The pattern of bands on TLC plates provides fundamental data and is used to demonstrate the consistency and stability of herbal components. It is a potent and rapid way to distinguish between chemical classes which may not be fulfilled by macroscopic and microscopic analysis. ${ }^{45}$ TLC is most recommended technique to create the fingerprints of herbal medicines because of its simplicity, versatility, specific sensitivity and easy sample preparation. ${ }^{46}$ Thus, TLC is a convenient method of determining the quality and possible adulteration of herbal 
Table 4: Preliminary phytochemical analysis of different solvent extracts of HP

\begin{tabular}{ccccccccccc}
\hline & HPHx & HPHp & HPBz & HPEa & HPC & HPAC & HPBu & HPEt & HPMt & HPAq \\
\hline Tannin & - & - & - & - & - & - & - & - & - & - \\
Triterpenoids & - & - & - & - & - & + & + & + & + & + \\
Amino acid & - & - & - & - & - & - & - & - & - & + \\
$\quad \begin{array}{l}\text { Resin } \\
\text { Cardiac }\end{array}$ & - & - & - & - & - & - & - & - & - & - \\
glycosides & + & + & + & ++ & + & ++ & + & + & ++ & ++ \\
$\begin{array}{l}\text { Flavonoids } \\
\text { Alkaloids }\end{array}$ & + & + & ++ & ++ & - & +++ & + & + & + & +++ \\
\hline
\end{tabular}

$(+++)$ appreciable amount; $(++)$ moderate; $(+)$ trace amount; (-) completely absent.

Table 5: In vitro antioxidant potential and quantitative phytochemical analysis of HP through successive solvents extraction

\begin{tabular}{|c|c|c|c|c|c|c|c|c|c|}
\hline & $\begin{array}{l}\text { DPPH IC } \\
(\mathrm{mg} / \mathrm{ml})\end{array}$ & $\begin{array}{l}\text { ABTS IC }_{50} \\
(\mathrm{mg} / \mathrm{ml})\end{array}$ & $\begin{array}{l}\mathrm{SOIC}_{50} \\
(\mathrm{mg} / \mathrm{ml})\end{array}$ & $\begin{array}{l}\mathrm{NOIC} \\
(\mathrm{mg} / \mathrm{ml})\end{array}$ & $\begin{array}{l}M C I C_{50} \\
(\mathrm{mg} / \mathrm{ml})\end{array}$ & $\begin{array}{c}\text { FRAP mg } \\
\text { AAE/mg EW }\end{array}$ & $\begin{array}{c}\text { TPC (mg Gallic } \\
\text { Acid eq./mg } \\
\text { EW) }\end{array}$ & $\begin{array}{c}\text { TFC (mg } \\
\text { quercetine } \\
\text { eq./mg EW) }\end{array}$ & $\begin{array}{c}\text { TOPC (mg } \\
\text { catechol eq./ } \\
\text { mg EW) }\end{array}$ \\
\hline HPHx & $2.156 \pm 0.148^{\mathrm{d}}$ & $0.171 \pm 0.003^{f}$ & NA & $\begin{array}{c}2.990 \pm \\
0.145^{\mathrm{a}}\end{array}$ & $0.976 \pm 0.084^{\mathrm{a}}$ & $9.311 \pm 0.030^{\mathrm{g}}$ & $94.353 \pm 0.074^{\mathrm{h}}$ & $12.627 \pm 0.042^{b}$ & $18.983 \pm 0.011^{\circ}$ \\
\hline НРНр & $0.653 \pm 0.003^{\mathrm{ab}}$ & $0.089 \pm 0.001^{c}$ & NA & NA & $0.328 \pm 0.036^{a}$ & $2.994 \pm 0.006^{c}$ & $361.413 \pm 0.00^{\mathrm{a}}$ & NA & $88.859 \pm 0.018^{a}$ \\
\hline $\mathrm{HPBz}$ & $1.094 \pm 0.256^{\mathrm{bc}}$ & $0.091 \pm 0.012 c^{d}$ & $7.147 \pm 0.073^{e}$ & NA & a & $4.955 \pm 0.088^{\mathrm{e}}$ & $139.2 \pm 0.082^{\mathrm{d}}$ & $15.459 \pm 0.045^{\mathrm{a}}$ & $14.128 \pm 0.004^{e}$ \\
\hline HPEa & $0.465 \pm 0.1667^{\mathrm{a}}$ & $0.062 \pm 0.001^{b}$ & $1.197 \pm 0.276^{\mathrm{b}}$ & $\begin{array}{c}3.516 \pm \\
0.379^{\mathrm{a}}\end{array}$ & NA & $1.889 \pm 0.084^{\mathrm{b}}$ & $176.077 \pm 0.238^{c}$ & $7.326 \pm 0.033^{\mathrm{d}}$ & $19.021 \pm 0.005^{\circ}$ \\
\hline $\mathrm{HPCl}$ & $1.511 \pm 0.057^{\mathrm{c}}$ & $0.065 \pm 0.003^{b}$ & $3.379 \pm 0.079^{c}$ & NA & $1.272 \pm 0.061^{\mathrm{a}}$ & $9.931 \pm 0.011^{\mathrm{h}}$ & $100.849 \pm 0.046^{\mathrm{g}}$ & NA & $33.443 \pm 0.02^{\mathrm{b}}$ \\
\hline HPAc & $0.256 \pm 0.034^{\mathrm{a}}$ & $0.037 \pm 0.004^{\mathrm{a}}$ & $0.782 \pm 0.311^{\mathrm{ab}}$ & $\begin{array}{c}5.046 \pm \\
0.476^{\mathrm{b}}\end{array}$ & $4.278 \pm 0.193^{c}$ & $1.064 \pm 0.029^{\mathrm{a}}$ & $272.988 \pm 0.2^{\mathrm{b}}$ & $15.387 \pm 0.071^{\mathrm{a}}$ & $17.406 \pm 0.044^{\mathrm{d}}$ \\
\hline HPBu & $0.612 \pm 0.023^{a}$ & $0.106 \pm 0.012^{\mathrm{d}}$ & $0.833 \pm 0.178^{\mathrm{ab}}$ & $\begin{array}{l}9.224 \pm \\
0.010^{\mathrm{d}}\end{array}$ & NA & $3.544 \pm 0.038^{\mathrm{d}}$ & $111.389 \pm 0.088^{f}$ & NA & $13.628 \pm 0.019^{f}$ \\
\hline HPEt & $3.288 \pm 0.594^{\mathrm{e}}$ & $0.249 \pm 0.002^{\mathrm{g}}$ & $4.482 \pm 0.511^{\mathrm{d}}$ & $\begin{array}{l}6.832 \pm \\
0.0568^{c}\end{array}$ & NA & $14.001 \pm 0.12^{\mathrm{i}}$ & $24.419 \pm 0.085^{j}$ & $1.126 \pm 0.006^{\mathrm{f}}$ & $5.902 \pm 0.007^{\mathrm{h}}$ \\
\hline HPMt & $1.243 \pm 0.148^{c}$ & $0.094 \pm 0.006^{\mathrm{cd}}$ & $12.331 \pm 0.158^{f}$ & NA & NA & $6.942 \pm 0.482^{\mathrm{f}}$ & $39.162 \pm 0.263^{\mathrm{i}}$ & $1.716 \pm 0.032^{\mathrm{e}}$ & $3.742 \pm 0.022^{\mathrm{i}}$ \\
\hline HPAq & $0.412 \pm 0.015^{\mathrm{a}}$ & $0.134 \pm 0.012^{\mathrm{e}}$ & $0.369 \pm 0.151^{\mathrm{a}}$ & $\begin{array}{c}29.608 \pm \\
0.416^{\mathrm{c}} \\
\end{array}$ & $3.10 \pm 0.946^{\mathrm{b}}$ & $1.726 \pm 0.028^{b}$ & $122.434 \pm 0.168^{\mathrm{e}}$ & $10.053 \pm 0.112^{c}$ & $13.556 \pm 0.077^{g}$ \\
\hline
\end{tabular}

Values with different letters ( $\mathrm{a}, \mathrm{b}, \mathrm{c}, \mathrm{d}, \mathrm{e}, \mathrm{f}, \mathrm{g}, \mathrm{h} \& \mathrm{i})$ are significantly $(\mathrm{p}<0.05)$ different from each other by Duncan's multiple range test (DMRT); NA: Not applicableAQ.

products. Over the ages, ethnomedicines have played a pivotal role in preventing and treating numerous human diseases and disorders. The credit of this ability may be given to the antioxidant potential of these plants used as ethnomedicine. For supporting the use of HP in traditional healing system, in vitro antioxidant activity of the various solvent extracts of HP was investigated. The previous studies have mentioned that no single method is sufficient to determine the antioxidant activity in a sample. ${ }^{47}$ Hence various free radical scavenging activities of different solvent extracts of $\mathrm{HP}$ was evaluated. In $\mathrm{DPPH}, \mathrm{ABTS}^{+}$and FRAP, acetone extract showed better activity along with high amount of TPC and TFC. Similar findings were noticed in Bergenia ciliata leaves where the acetone extract had exhibited significant free-radical scavenging property when compared with other non polar and polar compounds. ${ }^{48}$ Heptane extract exhibited highest TPC and TOPC as compared to other extracts while TFC was found to be highest in the benzene extract. Chelation of metal, SO and NO scavenging activity was more in HPHp, HPHx and HPAq respectively. From the overall result, it was observed that the efficacy of each extract varied against different free radicals in specific assays indicating the complexity of mechanisms and the diverse chemical nature of the active phytoconstituents present in plants. ${ }^{49}$ Qualitative phytochemical studies on the different solvent extracts of HP revealed that some solvents are good for extraction of phytoconstituents while some others are not so suitable. It is given in Table 4 that triterpenoids was present only in HPAc, HPBu, HPEt, HPMt and HPAq. Amino acids were found to be extracted only by the aqueous extract. Alkaloid was absent which was evidenced by the absence of Dragendorff's band in TLC method. All the extracts indicated the presence of cardiac glycosides and flavonoids particularly extracted by acetone and aqueous solvents in large amount. It could be assumed that the presence of the above phytoconstituents in some selected plant extracts alone or in combination might be credited for the antioxidant potential found in HP. To determine this view, Pearson correlation test was done between the phytochemical contents and the antioxidant activity of HP. The results in Table 6 showed a significant positive correlation between FRAP with DPPH and $\mathrm{ABTS}^{+}$while FRAP showed significant negative correlation with TPC indicating that phenolic content of HP might be responsible for causing ferric reducing potential. But there was no correlation between TPC, TFC and TOPC with the other radical scavenging activities of HP. Our observation supports the study of antioxidants on Fraxinus floribunda bark where no correlation was obtained between phenolics and antioxidant activity. ${ }^{50}$ Similar finding was also reported in a number of medicinal plant extracts in which no correlation was found between total phenol content and antioxidant capacity. ${ }^{51}$ Therefore it might be possible that there were other non-phenolic phytochemicals such as amino acids, uronic acids, ascorbic acid, 


\begin{tabular}{|c|c|c|c|c|c|c|c|c|}
\hline & DPPH & ABTS+ & so & NO & MC & FRAP & TPC & TFC \\
\hline ABTS $^{+}$ & $0.826^{* *}$ & - & - & - & - & - & - & - \\
\hline SO & 0.367 & 0.099 & - & - & - & - & - & - \\
\hline NO & -0.302 & 0.084 & -0.359 & - & - & - & - & - \\
\hline MC & -0.613 & -0.347 & -0.852 & 0.231 & - & - & - & - \\
\hline FRAP & $0.964^{* *}$ & $0.700^{*}$ & 0.422 & -0.308 & -0.586 & - & - & - \\
\hline TPC & -0.616 & -0.554 & -0.558 & -0.129 & 0.044 & $-0.660^{*}$ & - & - \\
\hline TFC & -0.496 & -0.482 & -0.423 & 0.000 & -0.044 & -0.548 & 0.741 & - \\
\hline TOPC & -0.244 & -0.263 & -0.461 & -0.259 & -0.528 & -0.220 & $0.781^{\star *}$ & $0.771^{\star}$ \\
\hline
\end{tabular}

${ }^{* *}$ Correlation is significant at the 0.01 level (2-tailed); ${ }^{*}$ Correlation is significant at the 0.05 level (2-tailed).

tocopherol, pigments etc which could be responsible for the antioxidant capacity. ${ }^{52,53}$ The strong positive correlation between DPPH and ABTS $^{+}$ suggests that the same phytoconstituents might be causing these free radicals scavenging activity of HP. TPC, TFC and TOPC were also found to be strongly correlated with each other.

\section{CONCLUSION}

All the scientific investigations support the traditional use of the powdered polyherb, HP for the treatment of heart problems which might be due to the accumulation of the free radicals. The Pearson correlation analysis suggested that the antioxidant potential possessed by HP was not due to phenolic compounds but it might be credited to other nonphenolic compounds found in plants. Further studies should be carried out in future using the animal models to confirm its antioxidant potential and its in vivo effectiveness of ethno-medicinal use. The data of pharmacognostic studies could be useful as a reference for the authentication and accurate identification of the polyherbal formulation, HP and also to differentiate it from its adulterants and alternatives.

\section{ACKNOWLEDGEMENTS}

We are thankful to the UGC for providing financial support under the scheme of Rajiv Gandhi National Fellowship. We are grateful to the Forests, Env. \& W/L Management Dept. Govt. of Sikkim, Gangtok for providing the permit for survey in West Sikkim. Our heartfelt gratitude towards Mr. Nar Bahadur Subba, an herbal practitioner for providing us the sample and the traditional knowledge of the formulation.

\section{CONFILCTS OF INTEREST}

Authors declare no conflict of interest.

\section{REFERENCES}

1. Gangwar KK, Gangwar D, Gangwar RS. Ethnomedicinal plant diversity in Kumaun Himalaya of Uttarakhand, India. Nature and Science 2010; 8(5): 66-78.

2. Das T, Mishra SB, Saha D, Agarwal S. Ethnobotanical survey of medicinal plants used by ethnic and rural people in eastern Sikkim Himalayan region. African J Basic and Appl Sci. 2012; 4(1): 16-20

3. Verma NS, Dwivedi S, Panigrahi D, Gupta SK. Anti-bacterial activity of root bark of Nyctanthes arbor-tristis Linn. Int J Drug Discovery and Herbal Res. 2011; 1(2): 61-2.

4. Dutta SC. Medicinal Plants. New Delhi: National Council for Education Research and Training; 1973

5. Panda AK. Medicinal plants of Sikkim in Ayurvedic practice. Regional Research Institute (Ayurvedic) Gangtok, Sikkim. c2007- [Accessed: 2010 Apr 16]. Available from: http://www. sikenvis.nic.in/docs/Ayurvedhic\%20 Medicines.pdf

6. Hussain W, Hussain J, Hussain S, Shinwari ZK, Ali R, Basir A. Ethono medicinal study of Parachinar, Kurram valley (fata) kpk, Pakistan. J App Pharm Sci. 2013; 3(11): 85-8.
7. Bhat JA, Kumar M, Rainer WB. Ecological status and traditional knowledge of medicinal plants in Kedarnath Wildlife Sanctuary of Garhwal Himalaya, India. J Ethnobiol Ethnomed. 2013; 9(1): 1-18.

8. Rajbhandari M, Mentel R, Jha PK, Chaudhary RP, Bhattarai S, Gewali MB, et al. Antiviral activity of some plants used in Nepalese traditional medicine. Evid Based Complement Alternat Med. 2009; 6(4): 517-22.

9. Ivanova D, Gerova D, Chervenkov T, Yankova T. Polyphenols and antioxidant capacity of Bulgarian medicinal plants. J Ethnopharmacol. 2005; 96(1): 145-50.

10. Kumar AD, Mazumder UK, Gupta M, Kumar GPS, Selvan VT. Evaluation of antioxidant and free radical scavenging activities of Oxystelma esculentum in various in vitro models. J Comp Integ Med. 2008; 5(1): 1-6.

11. Veerapur VP, Prabhakar KR, Parihar VP, Kandadi MR, Ramakrishana S, Mishra B, et al. Ficus racemosa stem bark extract: a potent antioxidant and a probable natural radioprotector. Evid Based Complement Alternat Med. 2009; 6(3): 317-24.

12. Ghosal M, Mandal P. In vitro antidiabetic and antioxidant activity of Calamus erectus Roxb. Fruit: a wild plant of Darjeeling himalaya. Int J Pharm Bio Sci. 2013; 4(2): 671-84

13. Mandal P, Misra TK, Singh ID, Das JK, Bhunia M. Free-Radical-Scavenging activity in the inflorescence of European Nettle/Sisnu (Urtica dioica L.). J Young Pharm. 2009; 1(2): 129-35.

14. Mukhia S, Mandal Singh DK, Singh D, Choudhury D. In vitro free-radical scavenging potential of three liverworts of Darjeeling himalaya. Int J Pharm Sci Res. 2014; 5(10): 4552-61.

15. Antolovich M, Prenzler P, Robards K, Ryan D. Sample preparation in the determination of phenolic compounds in fruits. Analyst. 2000; 125(5): 989-1009.

16. Sultana B, Anwar F, Przybylski R. Antioxidant activity of phenolic components present in barks of Azadirachta indica, Terminalia arjuna, Acacia nilotica, and Eugenia jambolana Lam trees. Food Chem. 2007; 104(3): 1106-14.

17. Sultana B, Anwar F, Ashraf M. Effect of extraction solvent/technique on the antioxidant activity of selected medicinal plant extracts. Molecules 2009; 14(6): 2167-80.

18. Kokate CK, Purohit AP, Gokhale SB. Text book of Pharmacognosy. $18^{\text {th }}$ ed. Pune: Nirali Prakashan; 2002.

19. Lala PK. Practical Pharmacognosy. $1^{\text {st }}$ ed. Calcutta: Lina; 1981

20. Chase $C R$, Pratt R. Fluorescence of powdered vegetable drugs with particular reference to development of a system of identification. J Am Pharmacol Assoc. 1949; 38 (6): 324-31.

21. Harborne JB. Phytochemical methods-A guide to modern techniques of plant analysis. Berlin: Springer Verlag; 2005

22. Kumar A, llavarasan $R$, Jayachandan $T$, Decaraman M, Aravindhan P, Padmanabhan N. Phytochemical investigation on a tropical plant, Syzygium cumini from Kattuppalayam, Erode District, Tamil Nadu, South India. Pak J Nutr. 2009; 8(1): 83-5.

23. Ngbede J, Yakubu RA, Nyam DA. Phytochemical screening for active compound in Canaruim schweinfurthii (Atile) leaves from los North, Plateau state, Nigeria. Res J Biol Sci. 2008; 3(9): 1076-8.

24. Ibrahim HA, Ibrahim $\mathrm{H}$. Phytochemical screening and toxicity evaluation on the leaves of Argemone mexicana Linn. (Papaveraceae). Int J Pure Appl Sci Technol. 2009; 3: 39-43.

25. Trease GE, Evans WC. Pharmacognosy. $13^{\text {th }}$ ed. London: Bailliere Tuidal; 1989. p. 799-80.

26. Wagner H, Bladt S. Plant Drug Analysis: A Thin Layer Chromatography Atlas. $2^{\text {nd }}$ ed. Berlin: Springer Verlag; 2009.

27. Chandler SF, Dodds JH. The effect of phosphate, nitrogen and sucrose on the production of phenolics and solasidine in callus cultures of Solanum laciniatum. Plant Cell Rep. 1983; 2(4): 205-8. 
28. Kim DO, Jeong SW, Lee CY. Antioxidant capacity of phenolic phytochemicals from various cultivars of plums. Food Chem. 2003; 81(3): 321-6.

29. Blois MS. Antioxidant determinations by the use of a stable free radical. Nature 1958; 181: 1199-200.

30. Re R, Pellegrini N, Proteggente A, Pannala A, Yang M, Rice-Evans C. Antioxidant activity applying an improved ABTS radical cation decolorization assay. Free Radic Biol Med. 1999; 26(9): 1231-7.

31. Nishikimi M, Appaji N, Yagi K. The occurrence of superoxide anion in the reaction of reduced phenazine methosulfate and molecular oxygen. Biochem Biophys Res Commun. 1972; 46(2): 849-54.

32. Marcocci L, Packer L, Droy-Lefaix MT, Sekaki A, Gardes-Albert M. Antioxidant action of Ginkgo biloba extract EGb 761. Methods Enzymol. 1994; 234: 462-75.

33. Dinis TC, Madeira VM, Almeida LM. Action of phenolic derivates (acetoaminophen, salycilate and 5-aminosalycilate) as inhibitors of membrane lipid peroxidation and as peroxyl radical scavengers. Arch Biochem Biophys. 1994; 315(1): 161-9.

34. Oyaizu M. Studies on products of browning reactions: antioxidative activities of products of browning reaction prepared from glucoamine. Jpn J Nutr. 1986; 4(6): 307-15

35. World Health Organization. Quality control methods for medicinal plant materials WHO/PHARM/92.559; 1998. p. 4-46.

36. Anonymous. Indian Pharmacopoeia, Vol-II, Ministry of Health and Family Welfare, Govt of India. New Delhi: Controller of Publications; 1996.

37. Khandelwal KR. Practical pharmacognosy technique and experiments. $23^{\text {rd }}$ ed. Pune: Nirali Prakashan; 2005. p. 149-56.

38. Purohit AP, Kokate CK, Gokhale SB. Pharmacognosy. $13^{\text {th }}$ ed. Pune: Nirali Prakashan; 2005. p. 256-9.

39. Kumar HD, Mannem K. A comparison study of macroscopical and microscopical characteristics of powder of Haritaki: Terminalia chebula (pericarp), Yavani: Ttrachyspermum ammi (fruit), Ajmoda: Apium leptophyllum (fruit) and Sunthi: Zingiber officinalie (rhizome). Int J Ayurveda Pharma Res. 2012; 3(2): 309-13.
40. Pavanasasivam G, Suktanbawa MU. Flavonoids of some Dilleniaceae species. Phytochem. 1975; 14(4): 1127-8.

41. Janchen D, Issaq HJ. Modern thin layer chromatography: advances and perspectives. J Liquid Chromatogr. 1988; 11(9-10): 1941-65.

42. Ansari SH. Essentials of Pharmacognosy. $1^{\text {st }}$ ed. New Delhi: Birla Publications Pvt. Ltd.; 2006.

43. African Pharmacopoeia. General methods for analysis, $1^{\text {st }}$ ed. Vol 2. Lagos; 1986. p. 123.

44. Dutta J. Phytochemicals analysis and TLC fingerprinting of methanolic extracts of three medicinal plants. Int Res J Pharm. 2013; 4(6): 123-6.

45. Folashade KO, Omoregie EH, Ochogu AP. Standardization of herbal medicines: a review. Int J Biodivers Conserv. 2012; 4(3): 101-12.

46. Mohammad A, Bhawani SA, Sharma S. Analysis of herbal products by thin layer chromatography: A review. Int J Pharm Biosci. 2010; 1(2): 1-50.

47. Erel O. A novel automated method to measure total antioxidant response against potent free radical reactions. Clin Biochem. 2004; 37(2): 112-9.

48. Mandal P, Misra T. In vitro evaluation of free-radical scavenging potential of pakhenbed leaves [Bergenia ciliata (Haw.) Sternb.]. Int J Nat Eng Sci. 2009; 3(1): 01-5.

49. Vaijanathappa J, Badami S, Bhojraj S. In vitro antioxidant activity of Enicostemma axillare. J Health Sci. 2008; 54(5): 524-8.

50. Subba A, Mandal P. Antioxidant potential of Fraxinus floribunda bark extracted through various aqueous processing. Free Rad Antiox. 2015; 5(1): 6-12.

51. Sengul M, Yildiz H, Gungor N, Cetin B, Eser Z, Ercisli S. Total phenolic content, antioxidant and antimicrobial activities of some medicinal plants. Pak J Pharm Sci. 2009; 22(1): 102-6.

52. Chye FY, Wong JY, Lee JS. Nutritional quality and antioxidant activity of selected edible wild mushrooms. Food Sci. Technol. Int. 2008; 14(4): 375-84.

53. Perez-Jimenez J, Saura-Calixto F. Antioxidant capacity of dietary polyphenols determined by ABTS assay: a kinetic expression of the results. Int $\mathrm{J}$ Food Sci Tech. 2006; 43(1): 185-9.

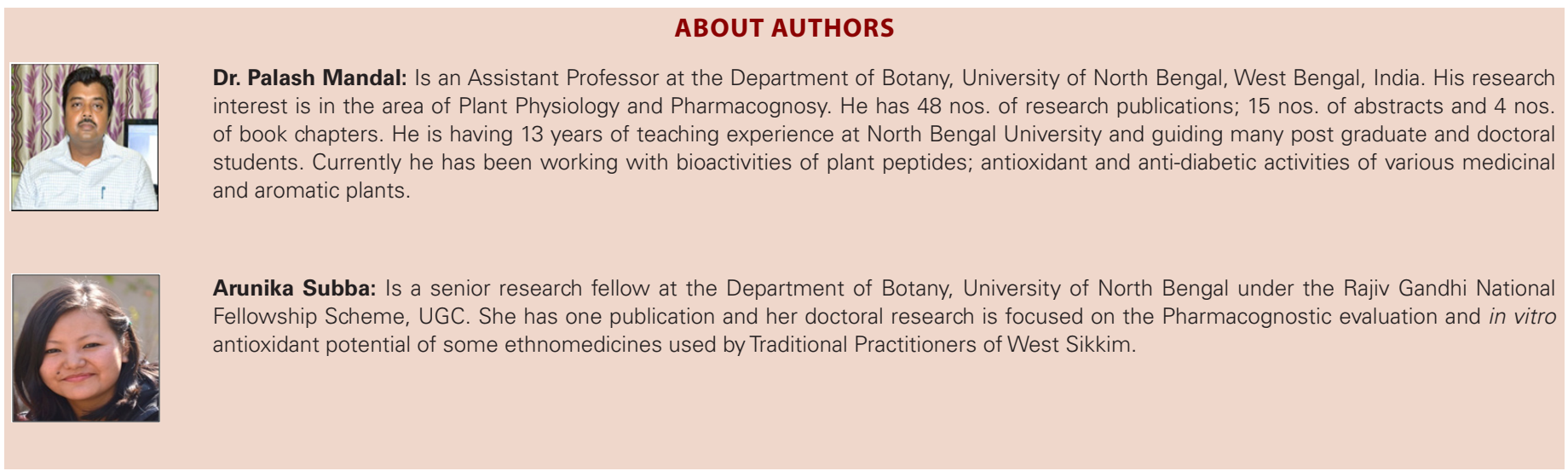

